ACTA UNIVERSITATIS NICOLAI COPER NICI

DOI: http://dx.doi.org/10.12775/AUNC_ECON.2015.011 EKONOMIA XLVI nr 2 (2015) 195-203

Pierwsza wersja złożona 5 października 2015

e-ISSN: 2392-1269

Końcowa wersja zaakceptowana 10 grudnia 2015

p-ISSN: 2080-0339

\title{
Mariusz Woźniakowski*
}

\section{CSR JAKO NARZĘDZIE KOMUNIKACJI MARKETINGOWEJ FIRM SEKTORA TSL **}

Z a r y s t r e ś c i. W artykule skupiono się na określeniu idei i roli jaką może odgrywać społeczna odpowiedzialność biznesu w komunikacji marketingowej przedsiębiorstw sektora TSL. Opisano sposób komunikowania przez wymienione podmioty działalności z zakresu CSR poprzez firmowe strony internetowe. Pokazano wybrane obszary zaangażowania oraz związek jaki istnieje pomiędzy działaniami o charakterze prospołecznym, a aktywnością z zakresu komunikacji marketingowej w firmach logistycznych.

S ł o w a k 1 u c z o w e: csr, komunikacja marketingowa, społeczne zaangażowanie.

K 1 a s y fik a j a J E L: M31, M37.

\section{WSTĘP}

Współczesny silnie konkurencyjny rynek stawia przed firmami coraz więcej wyzwań związanych z pozyskaniem i utrzymaniem klientów. W celu wyróżnienia na rynku, pokazania się z dobrej strony, firmy coraz częściej uwzględniają interesy społeczne, relacje z różnymi grupami interesariuszy czy ochronę środowiska już na etapie tworzenia strategii, co przekłada się na aktywne działania w obszarze CSR, a także pośrednio na sposób komunikowania tych działań do otoczenia.

Obecna działalność firm z zakresu społecznej odpowiedzialności biznesu w znacznym stopniu nie jest związana $\mathrm{z}$ działalnością stricto filantropijną

\footnotetext{
*Adres do korespondencji: Mariusz Woźniakowski, Uniwersytet Łódzki, Wydział Zarządzania, Katedra Marketingu, ul. Jana Matejki 22/26, 90-237 Łódź, e-mail: m.wozniakowski@uni.lodz.pl.

** Praca finansowana przez Uniwersytet Łódzki, Wydział Zarządzania.

(C) 2015 Uniwersytet Mikołaja Kopernika. All rights reserved. http://www.aunc.ekonomia.umk.pl
} 
podmiotu, chęcią poprawy humoru przez prezesa albo właściciela. CSR stał się prawidłową postawą względem społeczności, w której otoczeniu działalność jest prowadzona, wymaganą przez większość interesariuszy. Aktualnie znaczna część działań marketingowych oparta jest na relacjach międzyludzkich, a co się z tym wiąże - na ludzkich emocjach. Taki stan rzeczy sprawia, że marketerzy starają się wykorzystać możliwości, jakie niesie za sobą działalność prospołeczna. Zatem wsparcie działań z obszaru CSR może mieć także na celu kształtowanie poprawnych relacji z otoczeniem oraz kreowanie dobrego wizerunku przedsiębiorstwa lub jego poprawę (Gontarczyk, 2003, s. 26-28), co z kolei jest wykorzystywane w działaniach z zakresu public relations. Można zatem przyjąć założenie, że polityka z zakresu społecznej odpowiedzialności biznesu przedsiębiorstw działających na polskim rynku, w tym podmiotów branży TSL, zależy przede wszystkim od wyników finansowych oraz roli działań związanych z CSR w hierarchii strategii komunikacyjnych tychże jednostek (Woźniakowski, 2009, s. 105).

W artykule skupiono się na komunikowaniu przez firmy sektora TSL, sklasyfikowane na „Liście 500” dziennika „Rzeczpospolita”, działalności z zakresu społecznej odpowiedzialności poprzez firmowe strony internetowe. Pokazano wybrane obszary zaangażowania oraz związek jaki istnieje pomiędzy działaniami o charakterze prospołecznym, a aktywnością z zakresu komunikacji marketingowej, ze szczególnym uwzględnieniem public relations w powyższych podmiotach.

\section{ISTOTA SPOŁECZNEJ ODPOWIEDZIALNOŚCI BIZNESU}

Świadome, pełne zaangażowanie w kwestie społeczne oraz wpisanie ich w strategię, a także kulturę organizacyjną przedsiębiorstw zaczęto dostrzegać w połowie lat 90. ubiegłego stulecia (Aniszewska, 2010, s. 6). Jednak samo pojęcie CSR nie doczekało się jednoznacznej interpretacji do tej pory. Istnieją opinie, które uznają społeczną odpowiedzialność biznesu za narzędzie komunikacji firmy, wedle innych jest to konkretna strategia firmy czy nawet filozofia zarządzania, a podług jeszcze innych jest to zwyczajna fanaberia decydentów obliczona na chwilowy efekt lub zaspokojenie własnych egoistycznych potrzeb. Brak jednoznacznej definicji może być spowodowane tym, że sam CSR zależy od lokalnej kultury, stopnia rozwoju/zamożności kraju lub branży, w której firma funkcjonuje. Dlatego wydaje się uzasadnione pochylenie nad różnymi podejściami do tego pojęcia.

Już w 1971 Philip Kotler i Gerald Zaltman użyli terminu ,marketing społeczny" w odniesieniu do rozwiązywania problemów ogólnospołecznych za pomocą narzędzi marketingu komercyjnego (Wieczorkowska, 2003). 
W tym samym czasie Milton Friedman (1970) przyjął zgoła odmienne podejście, stwierdzając, że ,jedynym obowiązkiem społecznym biznesu jest działanie na rzecz udziałowców, czynności z zakresu CSR nie powinny mieć miejsca, gdy obniżają zysk firmy". Obecnie wydaje się, że omawiane pojęcie najczęściej utożsamiane jest z podejściem jakie reprezentuje Komisja Europejska, definiując CSR jako „koncepcję dobrowolnego uwzględniania przez firmę aspektów społecznych i ekologicznych podczas prowadzenia działań handlowych i w kontaktach z interesariuszami” (Krukowska, 2015).

Pomimo różnic $\mathrm{w}$ interpretacji pojęcia społecznej odpowiedzialności biznesu, w jednym należy być zgodnym - firma, która planuje wdrożyć działania z tego zakresu, powinna mieć świadomość, że staje przed znacznym wyzwaniem, ponieważ jest to droga, od której nie ma odwrotu. W przypadku ewentualnego wycofania się z działań CSR, firma w oczywisty sposób wystawia się na negatywne komentarze ze strony klientów, tracąc przy tym na wizerunku i wiarygodności w oczach kooperantów rynkowych (Stopczyńska, 2014, s. 747).

\section{ZWIAQZEK POMIĘDZY CSR A KOMUNIKACJĄ MARKETINGOWA}

Według Philipa Kotlera (2012) komunikacja marketingowa „to różne sposoby, na jakie firmy próbują informować i przekonywać konsumentów oraz przypominać im - bezpośrednio lub pośrednio - o produktach i markach, które mają w ofercie. W pewnym sensie komunikacja marketingowa jest głosem firmy i jej marek; sposobem, w jaki firma może ustanowić dialog i budować relacje z konsumentami”. Analizując przytoczoną definicję komunikacji marketingowej i wcześniejsze CSR, można uznać, że społeczna odpowiedzialność biznesu wpisuje się w nurt komunikacji w przedstawionej postaci. Jednak komunikacja marketingowa w tradycyjnym ujęciu składa się z kilku narzędzi: reklamy, promocji sprzedaży, public relations, marketingu bezpośredniego oraz sprzedaży osobistej. Patrząc przez pryzmat specyfiki poszczególnych narzędzi, wydaje się, że najliczniejsze związki będzie CSR dzielić $\mathrm{z}$ public relations.

$\mathrm{Z}$ praktycznego punktu widzenia public relations polega na stworzeniu i budowaniu właściwych kontaktów $\mathrm{z}$ otoczeniem za pomocą komunikowania. Proces ten definiuje się jako wzajemne oddziaływanie społeczne za pomocą komunikatów, które ma doprowadzić do wspólnego zrozumienia określonych treści (Weinstein, 1994, s. 223), co wpływa na kształtowanie opinii i postawy odbiorców wobec wystosowanych komunikatów. Zatem ,ppublic relations to proces takiej komunikacji między organizacją a jej otoczeniem, który doprowadzić ma do osiągnięcia zaplanowanych celów, przy użyciu 
odpowiednio dobranych środków i metod" (Piasta, 1996, s. 16). Wobec tego public relations można uznać za zespół celowo zorganizowanych działań, zapewniających przedsiębiorstwu systematyczne komunikowanie się z otoczeniem, mające wywołać pożądane postawy i działania (Gasparski i inni, 1992, s. 239), a więc może to być kreowanie wizerunku firmy odpowiedzialnej społecznie poprzez działania wykonywane w tym obszarze.

Związki pomiędzy społeczną odpowiedzialnością biznesu a public relations nie są kwestią do końca zbadaną i rodzą rozmaite pytania i kontrowersje. Dla niektórych marketerów CSR jest jednym z narzędzi PR'u. Inni uważają, że CSR powinien stanowić odrębną formę aktywności. Należy jednak zwrócić uwagę, że w wielu przypadkach obszary CSR i public relations nakładają się na siebie. Poza tym, w większości przedsiębiorstw podejmujących aktywne działania w obszarze zaangażowania społecznego, aktywności te prowadzone są właśnie przez działy public relations lub osoby bezpośrednio odpowiedzialne za PR, przez to praktycy PR najczęściej inicjują tego typu działalność. Rzadziej zdarza się, że CSRem zajmuje się osobny zespół pracowników (proto.pl, 2009). CSR często odbierany jest z nieufnością, nie jako szczera chęć pomagania innym, a jedynie jako środek do kreowania pozytywnego wizerunku. Dlatego public relations powinno być głównym narzędziem komunikacji o programach CSR. Należy pamiętać, że PR nie ma służyć udowadnianiu, że pomaganie jest naczelną wartością firmy, a wypracowywanie zysków, tylko efektem ubocznym (Okoń, 2009, s.23).

Większość największych firm, w tym te związane z TSL mają dość jasno zdefiniowane strategie zaangażowania społecznego, najczęściej są to długofalowe programy współpracy z partnerami społecznymi, wykorzystujące co najmniej 2-3 różne formy zaangażowania z kilkunastu możliwych. Możemy w tym obszarze rozpatrywać następujące formy wsparcia: bezpłatne przekazywanie produktów bądź usług; wolontariat pracowniczy; wsparcie finansowe (np. mecenat, sponsoring); wykorzystanie wpływu firmy na otoczenie; kampanie marketingu zaangażowanego społecznie (np. Podziel się posiłkiem); udostępnienie biura/lokalu; zakupy dokonywane na rynku lokalnym. Natomiast do mechanizmów współpracy można zaliczyć: fundacje korporacyjne (np. Fundacja Grupy PKP); programy ze znakiem firmowym korporacji (np. Grasz o staż); strategiczne partnerstwa przedsiębiorstw i organizacji pozarządowych; koalicje firm łączące działania na rzecz społeczeństwa $z$ interesem branży i/lub korzyściami firm (np. Global Road Safety Partnership); międzysektorowe koalicje lokalne (Greszta, Kozakiewicz, 2009).

Wszystkie wyżej wymienione aktywności mogą być wykorzystane w działaniach komunikacji z zakresu public relations przedsiębiorstwa, przy 
czym niektóre $\mathrm{z}$ nich mogą być potraktowane jako głównie narzędzie PRu (np. mecenat i sponsoring) a nie CSR.

Z pewnością coraz ważniejsza rola CSR w działalności przedsiębiorstw, w tym tych związanych z sektorem TSL, będzie prowadzić do powstawania pytań o jej rolę $w$ organizacji. Bez względu na to jaka będzie to pozycja względem public relations, nie ma wątpliwości, że aktywność w obrębie społecznego zaangażowania potęguje efekty PR'owe. Do zalet CSR w odniesieniu do prowadzonej działalności biznesowej należy wymienić m.in.: budowanie pozytywnego wizerunku organizacji; uwiarygodnienie misji w oczach klientów, dostawców, kooperantów, itd.; pozyskanie, względnie podtrzymanie zaufania i lojalności zarówno aktualnych jaki i potencjalnych klientów; pozyskanie przychylności społeczności lokalnej, w obrębie której firma funkcjonuje; przyczynienie się do poprawy wewnętrznej sytuacji w firmie (m.in. wzrost zadowolenia i satysfakcji pracowników, czy wzrost ich lojalności i chęci identyfikowania się z firmą; porto.pl, 2009).

Należy też zaznaczyć, że prowadzenie okazjonalnych działań z zakresu CSR powiązanych z PR'em nie wystarczy do uzyskania pozytywnych efektów i zbudowania reputacji marki. Istotne jest, żeby wspomniane inicjatywy miały wspólny mianownik, który jest w stanie utrwalić w pamięci odbiorców wyraźny i spójny wizerunek. Klient powinien mieć nie tylko świadomość, że dane przedsiębiorstwo przeznacza określone środki finansowe czy rzeczowe na działalność prospołeczną, ale również powinien rozumieć dlaczego w te, a nie inne działania się angażuje. Niestety w rzeczywistości okazuje się, że znaczna część badanych firm angażuje się w akcje nie do końca przemyślane. Wiele z nich komunikuje dość szeroką działalność społeczną, jednak dość chaotyczną lub wręcz nie wskazują żadnych konkretnych działań, co może doprowadzić do rozmycia wizerunku. Jak zatem dokonać właściwych wyborów związanych z realizacją projektów społecznych i jak sprawić, aby działalność ta przyniosła oczekiwane efekty, przyczyniając się chociażby do poprawy wizerunku? Podstawą jest zastosowanie głębokiego podejścia do marki i określenie wartości z jakimi ma się ona kojarzyć odbiorcom. Kolejnym krokiem powinno być określenie misji organizacji, która powinna przynieść odpowiedź na pytanie, co jest istotą marki i co wyróżnia ją na rynku. Misja powinna również wskazywać jakie działania należy podejmować, a jakie bezwzględnie nie (Woźniakowski, 2009, s. 108). 


\section{KOMUNIKOWANIE O SPOŁECZNYM ZAANGAŻOWANIU FIRM SEKTORA TSL POPRZEZ STRONY WWW}

Dla potrzeb niniejszego opracowania dokonano analizy kontentu stron internetowych firm z sektora TSL, będących w zestawieniu „Lista 500” największych polskich przedsiębiorstw, opublikowanym przez dziennik „Rzeczpospolita” w kwietniu 2014 (zgodnie z klasyfikacją PKD sklasyfikowane zostały w zestawieniu pod branżą transport). Zdecydowano się skorzystać $\mathrm{z}$ tego rankingu $\mathrm{z}$ uwagi na fakt, że najczęściej duże firmy są pionierami we wdrażaniu działań z zakresu CSR oraz posiadają adekwatne zasoby do prowadzenia działań prospołecznych, zakrojonych na dużą skalę.

Dokonując audytu zawartości stron www, sprawdzono po pierwsze czy firma za jej pośrednictwem komunikuje w obrębie misji, wizji lub swoich wartości na temat roli społecznej odpowiedzialności w jej codziennym funkcjonowaniu. Po drugie czy posiada (i o tym fakcie informuje na stronie) o prowadzonej fundacji korporacyjnej. Po trzecie gdzie w strukturze strony znajdują się informacje poświęcone ewentualnym działaniom $\mathrm{z}$ zakresu CSR.

Przeprowadzona analiza wykazała, że jedynie 5 spośród 22 firm (liczba ta daje branży 11 miejsce pod względem liczby podmiotów w zestawieniu) informuje o roli CSRu w jej funkcjonowaniu w ramach wymienionych wartości czy zasad zrównoważonego rozwoju (szczegółowy wykaz zaprezentowano w tabeli nr 1). Jednak bezpośredniego odniesienia do społecznej odpowiedzialności biznesu nie odnajdziemy w żadnej misji spośród badanych podmiotów. Tylko w jednym przypadku - Grupa PKP SA firma komunikuje o prowadzonej fundacji korporacyjnej. Fundacja Grupy PKP działa m.in. na rzecz ,krzewienia kultury, sztuki, ochrony dóbr kultury i dziedzictwa narodowego (...) związanych z tradycjami i historią kolejnictwa".

Znacznie więcej firm z sektora TSL komunikuje za pośrednictwem własnej strony www o prowadzonych działaniach CSR w ogóle. 11 z nich posiada w strukturze strony osobną zakładkę poświęconą tej formie aktywności, przy czym są one różnie nazywane w obrębie menu (CSR, społeczna odpowiedzialność, sponsoring, wspieramy, itp.). Dodatkowo spośród 11 wspomnianych przedsiębiorstw 5 podaje informacje na temat konkretnych działań prospołecznych w sekcji poświęconej bieżącym wydarzeniom w firmie. Kolejne 4 wspominają o działaniach CSR jedynie w aktualnościach. Reasumując w 15 z 22 analizowanych podmiotów odnajdziemy na stronie korporacyjnej informacje o prowadzonych działaniach z zakresu społecznej odpowiedzialności biznesu. 
Tabela 1. Komunikowanie o społecznym zaangażowaniu przez firmy sektora TSL poprzez korporacyjne strony www

\begin{tabular}{|c|c|c|c|c|c|c|c|}
\hline \multirow[t]{2}{*}{ Lp } & \multirow[b]{2}{*}{ 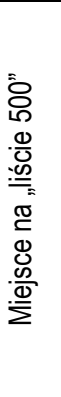 } & \multirow[t]{2}{*}{ Nazwa firmy } & \multirow[t]{2}{*}{ Adres www } & \multirow[b]{2}{*}{ 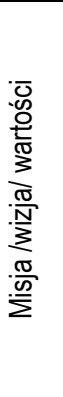 } & \multirow[b]{2}{*}{ 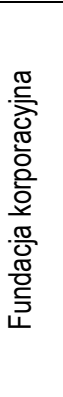 } & \multicolumn{2}{|c|}{$\begin{array}{l}\text { Miejsce infor- } \\
\text { macji o CSR na } \\
\text { stronie www }\end{array}$} \\
\hline & & & & & & 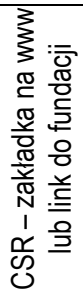 & 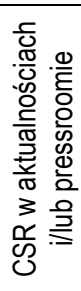 \\
\hline 1 & 16 & Grupa PKP SA & pkpsa.pl & - & Tak & Tak & Tak \\
\hline 2 & 56 & PKP Cargo SA & pkp-cargo.pl & - & - & - & - \\
\hline 3 & 67 & $\begin{array}{l}\text { PKP Polskie Linie Kolejowe } \\
\text { SA }\end{array}$ & plk-sa.pl & - & - & - & Tak \\
\hline 4 & 101 & Polskie Linie Lotnicze LOT & lot.com & - & - & Tak & Tak \\
\hline 5 & 156 & OGP Gaz-System SA & gaz-system.pl & Tak & - & Tak & Tak \\
\hline 6 & 161 & Grupa Raben sp. z o.o. & $\begin{array}{l}\text { polska.raben- } \\
\text { group.com }\end{array}$ & Tak & - & Tak & Tak \\
\hline 7 & 189 & Polska Żegluga Morska PP & polsteam.pl & - & - & - & - \\
\hline 8 & 228 & Schenker sp. z 0.0. & $\begin{array}{c}\text { logis- } \\
\text { tics.dbschenker. } \\
\text { pl/log-pl-pl/start/ }\end{array}$ & Tak & - & Tak & - \\
\hline 9 & 256 & Havi Logistics sp. z o.o. & $\begin{array}{c}\text { havi- } \\
\text { logistics.com }\end{array}$ & Tak & - & Tak & - \\
\hline 10 & 332 & $\begin{array}{c}\text { Tramwaje Warszawskie sp. } \\
\text { z o.0. }\end{array}$ & tw.waw.pl & - & - & - & Tak \\
\hline 11 & 336 & $\begin{array}{l}\text { Miejskie Zakłady Autobuso- } \\
\text { we sp. z 0.0. }\end{array}$ & mza.waw.pl & - & - & - & Tak \\
\hline 12 & 346 & $\begin{array}{c}\text { Przewozy Regionalne sp. z } \\
\text { o.0. }\end{array}$ & $\begin{array}{l}\text { przewozyregio- } \\
\text { nalne.pl }\end{array}$ & - & - & - & - \\
\hline 13 & 348 & DPD Polska sp. z o.o. GK & dpd.com.pl & Tak & - & Tak & Tak \\
\hline 14 & 389 & PERN Przyjaźń SA GK & pern.com.pl & - & - & - & - \\
\hline 15 & 402 & $\begin{array}{l}\text { Koleje Mazowieckie - KM } \\
\text { sp. z 0.0. }\end{array}$ & $\begin{array}{l}\text { mazowiec- } \\
\text { kie.com.pl }\end{array}$ & - & - & - & - \\
\hline 16 & 416 & Pol-Miedź Trans sp. z o.o. & pmtrans.com.pl & - & - & - & - \\
\hline 17 & 418 & Pekaes SA GK, Błonie & pekaes.pl & - & - & Tak & - \\
\hline 18 & 437 & Rohlig Suus Logistics SA & suus.com & - & - & Tak & - \\
\hline 19 & 447 & OT Logistics SA GK & $\begin{array}{l}\text { otlogisti- } \\
\text { cs.com.pl }\end{array}$ & - & - & - & Tak \\
\hline 20 & 458 & Gefco Polska sp. z o.o. & pl.gefco.net & - & - & Tak & - \\
\hline 21 & 480 & JAS-FBG SA & jasfbg.com.pl & - & - & Tak & Tak \\
\hline 22 & 482 & MPK SA & mpk.krakow.pl & - & - & - & - \\
\hline & & Suma „tak” & & 5 & 1 & 11 & 10 \\
\hline
\end{tabular}

Źródło: opracowanie własne. 


\section{PODSUMOWANIE}

Obserwując działalność największych firm sektora TSL na rynku polskim można stwierdzić, że idea społecznej odpowiedzialności ma coraz większy wpływ na kształtowanie marek. Jednak nadal widać wiele ułomności w sposobie komunikowania o działaniach CSR, a i sama aktywność wydaje się często nie do końca przemyślana, spójna z całościową strategią komunikacji marketingowej firmy. Fakt ten ma także odzwierciedlenie w innych raportach poświęconym CSR w polskim biznesie. Dla przykładu w cyklicznym raporcie BI-NGO pokazującym sposób komunikacji w obszarze CSR branża „transport i logistyka” została sklasyfikowana na 12 miejscu na 19 badanych.1 Na tej podstawie można wysnuć wniosek, że społeczna odpowiedzialność biznesu jest nadal obszarem nie do końca zagospodarowanym wśród firm sektora TSL. CSR jest szansą na zbudowanie pozytywnego, wyróżniającego wizerunku, pod warunkiem, że polityka ta będzie spójna i zrozumiała dla odbiorców oraz odpowiednio wspomagana przez działania z zakresu komunikacji marketingowej, w tym public relations. Tak prowadzona aktywność w obrębie CSR pozwoli na wyprzedzenie konkurencji poprzez zapadnięcie w umysłach odbiorców jako firmy - porządnego obywatela.

\section{LITERATURA}

Aniszewska G. (2010), CSR a kultura organizacyjna, ,Marketing i rynek” 12, 2-8.

Friedman M. (1970), The Social Responsibility of Business is to Increase Its Profits, „The New York Times Magazine", 33.

Gasparski L., Rutkowski I., Wrzosek W. (1992), Marketing. Punkt zwrotny nowoczesnej firmy, PWE, Warszawa.

Gontarczyk K. (2003), Firma prospoteczna, „Marketing w praktyce”, 1, 26-28.

Greszta M., Kozakiewicz M. (2009), Indeks BI-NGO 2009. Komunikowanie o społecznym zaangażowaniu firm w Internecie. Instrukcje dla badaczy, Instytut Partnerstwa Biznesu i Organizacji Pozarządowych BI_NGO, Łódź.

Kotler Ph., Keller K. L. (2012), Marketing, Rebis, Poznań.

Okoń M. (2009), Zwiąek między PR a CSR, „Gazeta Finansowa”, 18.09, 23.

Piasta Ł. (1996), Public relations. Istota techniki, Centrum Informacji Menedżera, Warszawa.

Stopczyńska K. (2014), Rola społecznej odpowiedzialności biznesu jako czynnika w ocenie wiarygodności partnerów handlowych, [w:] Raczkowski K. (red.), Bezpieczeństwo ekonomiczne obrotu gospodarczego, Wolters Kluwer SA, Warszawa.

Weinstein K. (1994), Komunikowanie się, [w:] Stewart D.M. (red.), Praktyka kierowania, PWE, Warszawa.

\footnotetext{
${ }^{1} \mathrm{http} / / / \mathrm{wwww} . c s r i n f o . o r g / \mathrm{pl} / \mathrm{component/content/article/4770-indeks-bi-ngo-2014}$ (17.09.2015).
}

AUNC, EKONOMIA XLVI nr 2 (2015) 195-203 
Wieczorkowska M. (2003), Elementy marketingu spotecznego i ich zastosowanie w kampanii antynikotynowej, ,Marketing i rynek”, 3, 24-30.

Woźniakowski M. (2009), Wykorzystanie idei społecznej odpowiedzialności $w$ dziataniach public relations instytucji bankowych, [w:] Piotrowska-Piątek A., Ruczkowski P. (red.), Wyzwania w systemie bankowym w XXI wieku, Wyższa Szkoła Ekonomii i Prawa w Kielcach.

\section{CSR AS MARKETING COMMUNICATION TOOL OF TSL SECTOR COMPANIES}

A b stract. The article focuses on identifying the idea and the role of corporate social responsibility in marketing communications of companies representing transport and logistics sector. Article describes how these entities communicate their CSR activities through the companies' website. Moreover the areas of companies' involvement in social activities are presented and relation that exists between social activities and marketing communication activities in transport and logistics sector.

K e y w o r d s: csr, marketing communication, corporate social responsibility. 
